\title{
Impact of Socio-Economic Variables of Customers on the Antecedents of Customer Experience Management in Retail Sector: An Evaluative Study
}

\author{
T. V.S. S. Swathi ${ }^{1}$ and V. Narasimha Rao ${ }^{2}$ \\ ${ }^{1}$ Research Scholar, ${ }^{2}$ Research Guide \\ ${ }^{1 \& 2}$ Department of Commerce \& Business Administration, Acharya Nagarjuna University, Andhra Pradesh, India \\ E-Mail:taddiswathi31@gmail.com, profvnrdirectormba@gmail.com
}

\begin{abstract}
In India there has been a tremendous change witnessed on the consumer behavior since the liberalization of Indian economy from the year 1990s. In a developing economy like India, the biggest challenge a retailer faces would be to tackle the ever-changing consumption practices. India is the world's fifth largest global destination in the retail space. The consumers in different socio-economic classes will generally have different priorities which will affect how they spend their money. It is essential on the part of retailers to understand socio-economic and demographic factors of consumers, affecting the antecedents of customer experience management in retail trade. This paper is an empirical analysis to know the socio-economic factors impact on consumer behavior in retail sector.
\end{abstract}

Keywords: Customer Experience, Organized Retailing, Shopping behavior, Antecedents

\section{INTRODUCTION}

The Indian retail industry has emerged as one of the most dynamic and fast-paced industries mainly due to the entry of several new players. Total consumption expenditure is expected to reach nearly US $\$ 3600$ billion by 2020 . It accounts for over 10 percent of the country's Gross Domestic Product (GDP) and around 8 percent of the employment. India is the world's fifth largest global destination in the retail space. India's retail market is expected to increase by 60 percent to reach US\$ 1.1 trillion by 2020 , on the back of factors like rising incomes and lifestyle changes by middle class and increased digital connectivity (Industrial Policy \& Promotion website).

Online retail sales have grown at the rate of 31 percent and reached US\$ 32.70 billion in 2018. According to the Department of Promotion of Industry and Internal Trade (DPIIT) the Indian retail trading has received Foreign Direct Investment (FDI) inflows totaling US\$ 1.59 billion during April 2000-December 2015. E-commerce is expanding steadily in the country, which is probably creating the biggest revolution in the retail industry. It is projected that by 2021 traditional retail will hold a major share of 75 percent, organized retail share will reach 18 percent and ecommerce retail share will reach 7 percent of the total retail market. Supported by the rising incomes, favorable demographics, entry of foreign players, Government initiatives and increasing urbanization, the long-term outlook for the industry is positive (FICCI \& Deloitte, 2018).
Socio-economic factors are the factors that shape and determine the dynamics, a society experiences. The most interesting behavior of members of a socio-economic class is the behavior of consumers and different socio-economic classes will generally have different priorities which will affect how they spend their money. Understanding the socio-economic factors affecting business will help to make better decisions in the business, the theoretical work on consumer behavior becomes more refined, the retail traders must keep pace and remain vigilant in the pursuit of deeper customer understanding (Olivia Durden, 2018). In the process of effective customer experience management, the retailers shall have insights into goals, information processing, memory, attitudes, affect, consumer attributions and choices (Nancy, Ronald, Dhruv, Robert, Priya \& David, 2009).

\section{REVIEW OF LITERATURE}

In order to understand retailing and consumer experiences, we must realize that consumers try to achieve the goal by purchasing and using a particular product or service (Ratneshwar, Mick and Huffman 2000). The study by Tauber 1972 suggests that personal and social needs motivate shopping beyond the simple need to acquire some product. According to Lee and Ariely (2006), goal evoking promotions are more effective in influencing consumers' behavior when goals are less concrete, such as early in the shopping process. Research should articulate how congruity between consumer goals and the retail environment influences consumer evaluation, search, and shopping behavior. The study by Donthu and Joseph 1994 revealed that involvement can interact with demographic variables to influence the need recognition stage of the consumer decision process. Among adolescents and their social networks, involvement with a retail channel significantly increases their communication about the time and money they spend in, and their future intentions to shop in that channel (Lueget al., 2006).

The research paper by 'Erna Andajani' (2015) titled "Understanding Customer Experience Management in Retailing" concluded that survival in today's economic climate and competitive retail business requires more than just low prices and innovative products. The concept of customer experience has emerged as a strategy for the retail business which is facing competition. Infosys white paper 
on 'Customer Experience for Retail Industry' found that to stay ahead of the competition, retailers shall look for ways to capture customer information and gain a holistic customer view across channels. Personalized customer experience solutions use innovative technologies and customer-centricity. Juan Bustamante and Natalio Rubio in their study felt that in a world where customer empowerment is continuously increasing and changing the service landscape, retailers must provide memorable shopping experiences to retain and attract new customers. Piyush Kumar Sinha \& Sanjay Kumar Kar (IIMA Working paper 2007) in their study on the growth of new retail formats in India revealed that retail sector in India is going through a transformation, so the emergent retail formats shall have a thorough understanding on the socio-economic and demographic profile of consumers.

\section{OBJECTIVES OF THE STUDY}

This paper aims to empirically evaluate the impact of socioeconomic variables of customers towards the customer experience management in the retail sector. The key antecedents of customer experience on the shopping behavior in retail businesses are considered in the study.

\section{DATA SOURCES AND METHODOLOGY}

This study is broadly based on a quantitative approach but in depth interviews with the customers while their shopping experiences in retail formats, forms some portion of qualitative approach used. This quantitative analysis is based on precise measurement using structured and validated data collection instrument. To realize the objective of knowing socio-economic factors impact on customer experience management in retail trade, primary data were obtained through administering a well-structured questionnaire. The secondary data were collected through published reports on retail trade, previous research works, books, newspapers and websites.

The geographical area of the study includes customers of retail formats namely supermarkets, departmental stores, hyper markets, malls, branded stores located in Vijayawada, Visakhapatnam and Tirupati cities in Andhra Pradesh State. The population for the study consists of customers in the age group of 18 to 70 years, who have been shopping from different formats of retail trade. The calculated size of sample for a population of 12.87 lakh with 5 percent margin of error at 95 percent level of confidence and with a response distribution of 50 percent is 384 respondents. The researcher has taken a sample size of 810 respondents which is greater than the calculated sample size. The statistical tests used in the study include Chi-Square test, ANOVA, Van der Waerden Two-Sample Test, Wilcoxon TwoSample Test, Kruskal Wallis Test.

\section{HYPOTHESES OF THE STUDY}

$H_{0 \text { : }}$ There exists no significant difference between the socioeconomic variables of customers on the selected antecedents of customer experience management in retail store (Age, gender, income, education, marital status, family size).

\section{ANALYSIS AND INTERPRETATION}

TABLE I SOCIO-ECONOMIC PROFILE OF RESPONDENTS

\begin{tabular}{|c|c|c|c|c|}
\hline $\begin{array}{l}\text { S. } \\
\text { No. }\end{array}$ & Variable & Classification & Frequency & Percentage \\
\hline \multirow{5}{*}{1} & \multirow{5}{*}{$\begin{array}{l}\text { Age (in } \\
\text { years) }\end{array}$} & $18-30$ & 487 & 60.12 \\
\hline & & $31-45$ & 225 & 27.78 \\
\hline & & $56-60$ & 78 & 9.63 \\
\hline & & Above 60 & 20 & 2.47 \\
\hline & & TOTAL & 810 & 100.00 \\
\hline \multirow{3}{*}{2} & \multirow{3}{*}{ Gender } & Male & 511 & 63.09 \\
\hline & & Female & 299 & 36.91 \\
\hline & & TOTAL & 810 & 100.00 \\
\hline \multirow{6}{*}{3} & \multirow{6}{*}{$\begin{array}{l}\text { Income } \\
\text { (per month } \\
\text { in Rupees) }\end{array}$} & $<15,000$ & 150 & 18.52 \\
\hline & & $15,000-30,000$ & 234 & 28.89 \\
\hline & & $30,000-50,000$ & 261 & 32.22 \\
\hline & & $\begin{array}{l}50,000- \\
1,00,000\end{array}$ & 97 & 11.98 \\
\hline & & $>1,00,000$ & 68 & 8.40 \\
\hline & & TOTAL & 810 & 100.00 \\
\hline \multirow{8}{*}{4} & \multirow{8}{*}{ Profession } & Student & 96 & 11.85 \\
\hline & & $\begin{array}{l}\text { Job in Public } \\
\text { Sector }\end{array}$ & 74 & 9.14 \\
\hline & & $\begin{array}{l}\text { Job in Private } \\
\text { Sector }\end{array}$ & 375 & 46.30 \\
\hline & & Business & 187 & 23.09 \\
\hline & & Home Maker & 38 & 4.69 \\
\hline & & Retired & 20 & 2.47 \\
\hline & & Professional & 20 & 2.47 \\
\hline & & TOTAL & 810 & 100.00 \\
\hline \multirow{6}{*}{5} & \multirow{6}{*}{$\begin{array}{l}\text { Educational } \\
\text { Qualification }\end{array}$} & Up to $10^{\text {th }}$ Grade & 16 & 1.98 \\
\hline & & Intermediate & 52 & 6.42 \\
\hline & & Graduate & 179 & 22.10 \\
\hline & & Post Graduate & 522 & 64.44 \\
\hline & & $\begin{array}{l}\text { Professional } \\
\text { course }\end{array}$ & 41 & 5.06 \\
\hline & & TOTAL & 810 & 100.00 \\
\hline \multirow{3}{*}{6} & \multirow{3}{*}{$\begin{array}{l}\text { Marital } \\
\text { Status }\end{array}$} & Married & 399 & 49.26 \\
\hline & & Unmarried & 411 & 50.74 \\
\hline & & TOTAL & 810 & 100.00 \\
\hline \multirow{6}{*}{7} & \multirow{6}{*}{ Family Size } & One & 24 & 2.96 \\
\hline & & Two & 44 & 5.43 \\
\hline & & Three & 126 & 15.56 \\
\hline & & Four & 397 & 49.01 \\
\hline & & More than four & 219 & 27.04 \\
\hline & & TOTAL & 810 & 100.00 \\
\hline
\end{tabular}


Majority of the respondents visiting the retail formats are in the age group of 18-70 years and Gender-wise majority constitutes male customers. Income-wise majority also constitutes male customers. Majority respondents were drawing a salary range of Rs.30, 000 - Rs.50, 000 per month. As regards the occupation, majority employed in private sector or self-employed. Educational qualification wise majority were post-graduates. In the marital status category majority were unmarried. The family size of the respondents indicates that about 73 per cent of the families had less than five members (Table I).

The summary of ANOVA test conducted on Age of respondents and store physical appearance indicates that $\mathrm{p}$ value $(<.0001)$ is less than 0.05 and hence the null hypothesis is rejected at 0.05 level of significance. Thus there seems a significant difference between the customers and 'loyalty' antecedent of customer experience management in retail store. (Table II).

Table II Cross Tabulation Of Age And Store Physical ApPearance

\begin{tabular}{|c|c|c|c|c|c|c|}
\hline \multirow{2}{*}{\multicolumn{2}{|c|}{ Physical Appearance }} & \multicolumn{4}{|c|}{ AGE (in years) Mean Scores } & \multirow{3}{*}{$\begin{array}{c}\text { p-value } \\
0.0115\end{array}$} \\
\hline & & \multirow{2}{*}{\begin{tabular}{|c|}
$\mathbf{1 8 - 3 0}$ \\
4.11 \\
\end{tabular}} & \multirow{2}{*}{\begin{tabular}{|c|}
$31-45$ \\
3.91
\end{tabular}} & \multirow{2}{*}{$\begin{array}{c}46-60 \\
3.94\end{array}$} & \multirow{2}{*}{$\begin{array}{c}\text { Above } 60 \\
4.00\end{array}$} & \\
\hline a & Outlet has modern-looking equipment and fixtures / racks & & & & & \\
\hline $\mathrm{b}$ & Outlet and its physical facilities are clean, convenient and visually attractive & 4.13 & 4.08 & 4.01 & 4.00 & 0.6420 \\
\hline $\mathrm{c}$ & Employees are always well dressed & 3.80 & 4.01 & 3.75 & 4.40 & 0.0029 \\
\hline $\mathrm{d}$ & Physical facilities are matching with the products / services offered by the store & 3.59 & 3.67 & 3.62 & 2.80 & 0.0054 \\
\hline \multicolumn{2}{|r|}{ Overall Result } & 4.03 & 4.04 & 3.91 & 4.00 & 0.3628 \\
\hline
\end{tabular}

The summary of the Van der Waerden test scores of customers Gender on 'physical appearance' antecedent indicates that p-value (0.0126) is lesser than 0.05 and hence the null hypothesis is rejected. Thus there exists significant difference between the male and female customers on the 'physical appearance' antecedent of customer experience management in retail store (Table III).
The summary of the Median One-way analysis conducted on customer profession on 'physical appearance' revealed that the p-value (0.6727) is greater than 0.05 and hence the null hypothesis is accepted at 0.05 level of significance. It can be viewed that there are no significant differences between the customers' profession and 'physical appearance' antecedent of customer experience management in retail store (Table IV).

TABle III MEAN SCORES Of Customers Gender ON ‘PhySicAl APPEARANCE’ ANTECEDENT

\begin{tabular}{|c|l|c|c|c|}
\hline \multicolumn{2}{|c|}{ Physical Appearance } & \multicolumn{2}{c|}{ Gender Mean Scores } & \multirow{2}{*}{ p-value } \\
\cline { 3 - 4 } \multicolumn{2}{|c|}{} & Male & Female & \\
\hline a & Outlet has modern-looking equipment and fixtures / racks & 4.00 & 4.10 & 0.0837 \\
\hline b & Outlet and its physical facilities are clean, convenient and visually attractive & 4.03 & 4.22 & 0.0053 \\
\hline c & Employees are always well dressed & 3.86 & 3.88 & 0.8220 \\
\hline d & Physical facilities are matching with the products / services offered by the store & 3.60 & 3.59 & 0.8833 \\
\hline \multicolumn{2}{|c|}{ Overall Result } & 3.98 & 4.09 & 0.0126 \\
\hline
\end{tabular}

Table IV Mean Scores Of Customers Profession On ‘Physical ApPearanCe’ ANTECEDENT

\begin{tabular}{|c|c|c|c|c|c|c|c|c|c|}
\hline \multirow{2}{*}{\multicolumn{2}{|c|}{ Physical Appearance }} & \multicolumn{7}{|c|}{ Profession Mean Scores } & \multirow{3}{*}{$\begin{array}{c}\begin{array}{c}\text { p- } \\
\text { value }\end{array} \\
0.0218\end{array}$} \\
\hline & & \multirow{2}{*}{$\begin{array}{c}\text { Student } \\
4.16 \\
\end{array}$} & \multirow{2}{*}{$\begin{array}{c}\text { Job in } \\
\text { Public } \\
\text { Sector }\end{array}$} & \multirow{2}{*}{$\begin{array}{c}\begin{array}{c}\text { Job in } \\
\text { Private } \\
\text { Sector }\end{array} \\
4.02 \\
\end{array}$} & \multirow{2}{*}{$\begin{array}{c}\text { Business } \\
4.13\end{array}$} & \multirow{2}{*}{$\begin{array}{c}\text { Home } \\
\text { maker }\end{array}$} & \multirow{2}{*}{$\begin{array}{c}\text { Retired } \\
3.60 \\
\end{array}$} & \multirow{2}{*}{$\begin{array}{c}\text { Professional } \\
3.80\end{array}$} & \\
\hline $\mathrm{a}$ & $\begin{array}{l}\text { Outlet has modern-looking equipment } \\
\text { and fixtures / racks }\end{array}$ & & & & & & & & \\
\hline $\mathrm{b}$ & $\begin{array}{l}\text { Outlet and its physical facilities are } \\
\text { clean, convenient and visually attractive }\end{array}$ & 4.00 & 3.90 & 4.14 & 4.17 & 3.97 & 4.20 & 4.20 & 0.2690 \\
\hline c & Employees are always well dressed & 3.79 & 4.06 & 3.85 & 3.81 & 4.02 & 4.40 & 3.60 & 0.0481 \\
\hline d & $\begin{array}{l}\text { Physical facilities are matching with the } \\
\text { products / services offered by the store }\end{array}$ & 3.58 & 3.55 & 3.55 & 3.63 & 4.21 & 3.00 & 4.00 & 0.0007 \\
\hline & Overall Result & 4.00 & 4.06 & 4.02 & 4.02 & 4.10 & 4.00 & 3.80 & 0.6727 \\
\hline
\end{tabular}

In order to know the impact of customer educational qualification on the 'physical appearance' antecedents of customer experience management in retail, the Van der Waerden One-way analysis is conducted. It indicated that p-value (0.0219) is less than 0.05 and hence the null hypothesis is rejected. It can be interpreted that there are no significant differences between the customers' education and 'physical appearance' antecedent of customer experience management in retail store (Table V). 
Table V Mean Scores Of Customers Education Qualification On ‘Physical ApPearance’ Antecedent

\begin{tabular}{|c|c|c|c|c|c|c|c|}
\hline \multirow{2}{*}{\multicolumn{2}{|c|}{ Physical Appearance }} & \multicolumn{5}{|c|}{ Education Mean Scores } & \multirow{3}{*}{$\begin{array}{c}\begin{array}{c}\text { p- } \\
\text { value }\end{array} \\
<.0001\end{array}$} \\
\hline & & \multirow{2}{*}{$\begin{array}{c}\begin{array}{c}\text { Up to } 10^{\text {th }} \\
\text { Grade }\end{array} \\
3.75 \\
\end{array}$} & \multirow{2}{*}{$\begin{array}{c}\text { Intermediate } \\
4.46\end{array}$} & \multirow{2}{*}{$\begin{array}{c}\text { Graduation } \\
3.82\end{array}$} & \multirow{2}{*}{$\begin{array}{c}\begin{array}{c}\text { Post } \\
\text { Graduation }\end{array} \\
4.12 \\
\end{array}$} & \multirow{2}{*}{$\begin{array}{c}\begin{array}{c}\text { Professional } \\
\text { Degree }\end{array} \\
3.51 \\
\end{array}$} & \\
\hline a & $\begin{array}{l}\text { Outlet has modern-looking equipment and } \\
\text { fixtures / racks }\end{array}$ & & & & & & \\
\hline $\mathrm{b}$ & $\begin{array}{l}\text { Outlet and its physical facilities are clean, } \\
\text { convenient and visually attractive }\end{array}$ & 3.50 & 4.07 & 4.06 & 4.13 & 4.12 & 0.0917 \\
\hline $\mathrm{c}$ & Employees are always well dressed & 4.25 & 3.53 & 3.82 & 3.93 & 3.53 & 0.0029 \\
\hline $\mathrm{d}$ & $\begin{array}{l}\text { Physical facilities are matching with the } \\
\text { products / services offered by the store }\end{array}$ & 3.75 & 3.53 & 3.64 & 3.57 & 3.73 & 0.7901 \\
\hline & Overall Result & 4.00 & 4.00 & 3.93 & 4.07 & 3.82 & 0.0219 \\
\hline
\end{tabular}

With a view to understand the customers' Marital Status impact on 'physical appearance' antecedent of customer experience management, Kruskal Wallis test conducted and its results indicated that p-value $(0.2108)$ is greater than 0.05 and hence the null hypothesis is accepted at 0.05 level of significance. It can be understood that there are no significant differences between the customers' marital status and 'responsiveness' antecedent of customer experience management in retail formats (Table VI).

Table Vi Mean Scores Of Customers Marital Status On ‘Physical ApPearance’ Antecedent

\begin{tabular}{|c|l|c|c|c|}
\hline \multicolumn{2}{|c|}{ Physical Appearance } & \multicolumn{2}{c|}{$\begin{array}{c}\text { Marital Status } \\
\text { Mean Scores }\end{array}$} & \multirow{2}{*}{ p-value } \\
\cline { 3 - 5 } \multicolumn{2}{|c|}{} & Married & Unmarried & \\
\hline a & Outlet has modern-looking equipment and fixtures / racks & 3.87 & 4.20 & $<.0001$ \\
\hline b & Outlet and its physical facilities are clean, convenient and visually attractive & 4.06 & 4.15 & 0.1621 \\
\hline c & Employees are always well dressed & 3.87 & 3.86 & 0.8440 \\
\hline d & Physical facilities are matching with the products / services offered by the store & 3.61 & 3.59 & 0.7597 \\
\hline \multicolumn{2}{|r|}{ Overall Result } & 3.96 & 4.08 & 0.0053 \\
\hline
\end{tabular}

The customers' family size impact on 'physical appearance' antecedent of customer experience management is tested with Median One-way analysis. The summary of this test indicated that p-value $(0.0045)$ is less than 0.05 and hence the null hypothesis in this regard is rejected at 0.05 level of significance, so there are no significant differences between the customers family size and 'physical appearance' antecedent of customer experience management in retail store (Table VII).

Table ViI Mean Scores Of Customers Family Size On ‘Physical ApPearance’ Antecedent

\begin{tabular}{|c|c|c|c|c|c|c|c|}
\hline \multirow{2}{*}{\multicolumn{2}{|c|}{ Physical Appearance }} & \multicolumn{5}{|c|}{ Family Size Mean Scores } & \multirow{3}{*}{$\begin{array}{c}\begin{array}{c}\text { p- } \\
\text { value }\end{array} \\
0.0002\end{array}$} \\
\hline & & \multirow{2}{*}{$\begin{array}{c}\text { Single } \\
4.00\end{array}$} & \multirow{2}{*}{\begin{tabular}{|l|} 
Two \\
4.09
\end{tabular}} & \multirow{2}{*}{$\begin{array}{c}\text { Three } \\
3.74\end{array}$} & \multirow{2}{*}{\begin{tabular}{r|} 
Four \\
4.12
\end{tabular}} & \multirow{2}{*}{$\begin{array}{c}\begin{array}{c}\text { More } \\
\text { than Four }\end{array} \\
4.05 \\
\end{array}$} & \\
\hline a & Outlet has modern-looking equipment and fixtures / racks & & & & & & \\
\hline $\mathrm{b}$ & Outlet and its physical facilities are clean, convenient and visually attractive & 3.50 & 4.45 & 4.25 & 4.07 & 4.06 & 0.0003 \\
\hline $\mathrm{c}$ & Employees are always well dressed & 4.00 & 4.45 & 3.78 & 3.81 & 3.90 & 0.0008 \\
\hline $\mathrm{d}$ & Physical facilities are matching with the products / services offered by the store & 3.00 & 3.90 & 3.69 & 3.54 & 3.65 & 0.0063 \\
\hline & Overall Result & 3.83 & 4.27 & 3.96 & 3.98 & 4.09 & 0.0045 \\
\hline
\end{tabular}

\section{MAJOR FINDINGS OF THE STUDY}

1. This study was conducted on the respondents particularly who have visited specific retail formats. Majority customers visiting the retail formats belong to the age group of 18-30 years. Gender-wise majority customers are males.

2. Income-wise, majority respondents' salary consists of Rs.30, 000 to Rs.50, 000 per month. Majority customers who visit the retail formats have been the employees in private sector organizations.
3. The literacy profile of the customers reveals the fact that customers visiting the different forms of retail outlets are well educated and majority happens to be with post-graduate qualification.

4. Compared with other categories of respondents' majority visiting the retail stores were unmarried. At the same time about 70 per cent of the respondents' families have less than five members in their family which indicates that the size of the family has been shrinking. 
5. On the physical appearance of the retail store formats the respondents expressed the view that the physical facilities in the retail formats are clean, convenient and visually attractive. The retail outlets are maintaining convenient timings.

6. Customers are satisfied with service quality of the retail formats and the customer care by the retail operators has been satisfactory. Further, the respondents felt it as convenient to move around the outlets and much care is taken on safety.

7. The personal attention paid by the retail format staff also lead to some comfort and convenience in selecting the products as per their needs and requirements at the retail store.

8. The customers feel good and benefited with promotional offers provided by the retailer and the trustworthiness of the retailer towards customers' interests.

9. The customers of retail formats are satisfied with the flexible pricing of the retailer on various products, scope for learning new things and the experience in the retail formats making them for repeat purchase.

10. The mean values of respondent customers on various items of retail stores reveal that their experience is 'smart' and majority felt that it is dynamic, stylish and good reception. However some felt that the stores are busy, tedious and irritating.

\section{CONCLUSION}

With the advent of liberalized economy from 1990, there has been a revolutionary change in the consumer behavior in India. The retail traders are required to put greater efforts to manage the customer experiences. The entry of global retailers like Wal-Mart, Tesco, Carrefour and Indian leading corporate houses like Tata, Reliance and Aditya Birla into retail trade created a surge into the growth of organized retail in India. The retail industry in India is the largest employer after agriculture. It is very important to understand the consumer behavior for better customer experience management by the retailers. It is a common knowledge that the growth of modern retailing in India has been much slower compared with other countries. In view of the changing demographics, urbanization, awareness, lifestyles, the consumers have wide option to choose modern retail formats. Hence the retailers need to innovate, design the value proposition and shall strive to serve the customer better, faster and at least cost. Till today there seems a vast and untapped potential in rural India. The retailers in the organized sector have to go a long way in understanding the consumer needs, tastes, culture and beliefs, so that they will be able to overcome the problems of deep rooted organized retail in India.

\section{REFERENCES}

[1] Department of Industrial Policy and Promotion website.

[2] Consumer Leads Report by FICCI and Deloitte - October 2018.

[3] Olivia Durden. (2018). "Socio-economic factors affecting small businesses".

[4] Nancy M. Pucinelli, Ronald C. Goodstein, Dhruv Grewal, Robert Price, Priya Raghubir, \& David Stewart. Customer Experience Management in Retailing: Understanding the Buying Process. Journal of Retailing, 85 (1-2009), 15-30.

[5] Consumers \& Markets, Marketing White Book.

[6] Non Store Retailing, Retailing in India, Euromonitor Report 2006.

[7] FICCI (2005). Indian Retail: On the Fast Track : Time for Bridging Capacity Gap.

[8] Kamal and Ashish Kumar (2014). Retail Sector - Growth and Challenges perspectives in India. International Journal of Emerging Technologies, 5(1), 69-73.

[9] The Global Retail Development Index, A.T. Kearney.

[10] Retrieved From www.indianretailing.com

[11] Retrieved From www.retailspace.com

[12] Retrieved From www.thehindubusinessline.com

[13] Vemanna N \& Rao, V.N. (2015). Consumer Behavior towards organized retailing - A study with special reference to selected retail chains. Doctoral Research Work. 